\title{
Terms-of-Trade Shocks and the Current Account
}

\author{
Wai Mun Chia \\ Nanyang Technological University \\ Joseph D. Alba \\ Nanyang Technological University
}

\begin{abstract}
We investigate the relationship between terms-of-trade shocks and the current account of a small open economy in the presence of imperfect competition and nominal price rigidities in the nontraded sector. We show that a temporary termsof-trade improvement results in a current account surplus since the increase in consumption of traded goods is smaller than the magnitude of terms-of-trade shock. This result is consistent with the well-known Harberger-Laursen-Metzler effect. However, the effects of permanent term-of-trade shocks on current account depend mainly upon the intra- and intertemporal elasticities of substitution in consumption. When prices are perfectly flexible, permanent terms-of-trade shocks have no dynamic effects on the current account.
\end{abstract}

- JEL Classifications: F32, F41

- Key words: Current account, Terms-of-trade, Imperfect competition, Nominal price rigidities, Harberger-Laursen-Metzler effect

\section{Introduction}

Terms-of-trade disturbances are regarded as a major source of output and current account fluctuations in a small open economy by many economists (see Mendosa,

\footnotetext{
*Corresponding address: Wai Mun Chia, School of Humanities and Social Sciences, Division of Economics, Nanyang Technological University, Nanyang Avenue, Singapore 639798, Tel: +65-67904290, Fax: +65-6790-6559, E-mail: aswmchia@ntu.edu.sg (C)2005-Center for International Economics, Sejong Institution, All Rights Reserved.
} 
1995 and Kose, 2002). This is particularly true for developing countries, whose export earnings are dominated by a narrow range of primary commodities (Kose, 2002). Since the prices of these primary commodities are subjected to large price fluctuations in the world market, terms-of-trade fluctuations in developing countries are observed to be more volatile than that of industrialized countries. Given the significance of terms-of-trade fluctuations on domestic macroeconomic variable, understanding the transmission and propagation of terms-of-trade fluctuations is crucial in the design and conduct of macroeconomic policies in both industrialized and developing countries.

The relationship between terms-of-trade and trade balance and/or current account has always been a perennial research topic in international macroeconomics ever since the seminal work of Harberger (1950) and Laursen and Metzler (1950). In this work, the authors argued that in a Keynesian framework with marginal propensity to consume less than unitary, a favorable terms-of-trade shock induces an increase in savings and net exports of the economy because a rise in the purchasing power of exports improves real income. Similarly, savings and net exports are lower when terms-of-trade worsens because the reduction in the purchasing power of exports decreases real income. This theoretical development in the literature has subsequently been known as the Harberger-Laursen-Metzler (HLM) effect.

The theoretical proposition of HLM has then been subjected to considerable scrutiny since the 1980s which has further induced a strong motivation for the international macroeconomic researchers to extend this proposition in many different directions. Using an intertemporal utility maximizing approach, Obstfeld (1983) and Svensson and Razin (1983) showed that with perfect capital mobility, price flexibility and competitive world capital market, the relationship between terms-of-trade and current account depends on the degrees of persistence in the terms-of-trade shocks. In general, they found that HLM effect results only with transitory or temporary terms-of-trade shocks. When there is a temporary deterioration in terms-of-trade, borrowing from abroad by rational agents to smooth consumption will worsen the current account. In sharp contrast to the HLM effect, a permanent terms-of-trade deterioration leaves current account unaffected. This is because rational agents will revise their expected current and future income downward when the shock is permanent without changing savings. However, these theoretical predictions were found to be inconsistent with the empirical regularities documented by Mendoza (1995). In Mendoza, current account and terms-of-trade are positively correlated which are consistent with the Obstfeld-Svensson-Razin 
framework, but the fact that these positive correlations are observed to be independent of the persistence of terms-of-trade shocks rises challenges to the intertemporal model.

In an attempt to examine the inconsistency between theoretical predictions provided by Obstfeld-Svensson-Razin and empirical regularities documented by Mendoza, we develop an intertemporal optimizing model with the existence of imperfect competition and nominal price rigidities. As a result, our model is different compared to the past literature which examined the relationship between terms-of-trade and current account by focusing on flexible-price economies and assuming away the awkward reality of nominal price rigidities. Since empirical regularities indicate that terms-of-trade shocks play a crucial role in determining real variables, such as current account, this yields legitimacy to incorporate nominal price rigidities in the model to provide a candidate explanation for the real effects of terms-of-trade shocks ${ }^{1}$. This line of research which develops extensively after the seminal work of Obstfeld and Rogoff (1995) is widely known as the New Open Economy Macroeconomics and its theoretical development, as identified by Obstfeld $^{2}$, has allowed economists to tackle classical problems with new tools, while also generating new ideas and questions.

After relaxing the restrictive assumptions of perfect price flexibility and competitive markets, we are able to obtain few results which are consistent with Mendoza's empirical regularities. First, the Harberger-Laursen-Metzler effect holds for a temporary terms-of-trade shock both in an economy with perfect price flexibility and competitive markets, and in an economy with nominal price rigidities and imperfect competitive markets. Second, in contrast to the ObstfeldSvensson-Razin intertemporal utility maximization approach which found that permanent terms-of-trade shocks leave the current account unchanged, our model shows that permanent terms-of-trade shocks have no dynamic effects on the current account only in the world of perfect price flexibility and competitive markets. Third, in the presence of nominal price rigidities and imperfect

\footnotetext{
${ }^{1}$ In Mendoza (1995), the co-movements between these variables are observable once uncertainty, capital accumulation, and structural differences in tastes and technology are considered, without abandoning the assumptions of perfect capital mobility, price flexibility and competitive capital markets. As a result, he concluded that the observed low correlations between trade balance and terms-of-trade (and independence of these correlations to terms-of-trade autocorrelations) are not indicators of credit constraints or lack of capital mobility.
}

${ }^{2}$ See Obstfeld, 2002 
competition, permanent terms-of-trade disturbances may have a positive effect or negative effect on the current account, which mainly depends upon the inter- and intratemporal elasticities of substitution in consumption. This result is shown to be consistent with the empirical regularities observed in Mendoza. As a result, we claim that nominal price rigidities play a crucial role in determining the current account dynamics when shocks are permanent.

This paper seeks to integrate the intertemporal equilibrium framework with nominal price rigidities and imperfect competitive markets to analyze the dynamics of current account arising from term-of-trade fluctuations. We adapt the model of Lane $^{3}$ (2000) and construct an intertemporal framework with tradable and nontradable sectors. The existence of traded and nontraded goods introduces additional features into the analysis and provides a richer framework for analyzing the current account dynamics in the face of terms-of-trade fluctuations. Past literature which took into account of nontraded goods include the work of Edwards (1989), Gavin (1990) and Cashin and McDermott (1998). By incorporating nontraded goods, the model is extended to involve both intertemporal and intratemporal substitution effects. For instance, in these studies, a temporary improvement in terms-of-trade will affect the dynamics of saving and current account in three ways. First, a decrease in the price of import increases the current income relative to future income. Saving increases as rational agents smooth their consumption (consumption-smoothing effect). Second, a decrease in the price of import leads to a cheaper current import relative to future import. As a result, current consumption on importable increases and saving is lower (consumptiontilting effect). Finally, a decrease in the price of import will lead to a depreciation of real exchange rate, which in turn decreases the consumption rate of interest. This will provide rational agents with the incentive to increase current consumption and decrease saving (real exchange rate effect). As a result, a temporary improvement in terms-of-trade will only improve the current account when the consumptionsmoothing dominates the consumption-tilting and real exchange rate effect.

In our model, the nontraded sector is assumed to be a monopolistic competitive market ${ }^{4}$ where prices in this monopolistic nontraded sector are set one period in

${ }^{3}$ This model was originally used to show that countries with net external liabilities have larger depreciation in real exchange rates where the main channel of transmission works through the relative price of nontraded goods, rather than through the relative price of traded goods across countries.

${ }^{4}$ We follow the assumption in Lane (2000) that the domestic aggregate demand conditions matter more for the nontraded sector than the traded sector. 
advance and they adjust to shocks only by period two. In other words, prices in the nontraded sector are sticky in the short run. The traded sector, on the other hand, is viewed as a perfectly competitive market where prices are fully flexible and covered by the law of one price. The asymmetric treatment between these two sectors allows us to show the link between these two sectors when there is a termsof-trade disturbance. We show clearly the propagation mechanism of terms-oftrade shocks on the dynamics of the current account where terms-of-trade shocks first perturb consumption in the traded sector in both the short run and the long run which eventually leads to a change in consumption in the nontraded sector and net foreign asset position of the country.

The structure of this paper is organized as follows. Section 2 lays out the theoretical model. The effects of a permanent and a temporary terms-of-trade shock are analyzed in section 3 and 4 respectively. Conclusions are offered in section 5 .

\section{The Model}

In this section an intertemporal model of a small open economy is derived to analyze the way in which different terms-of-trade deterioration - temporary and permanent - affects the current account. This model is adapted from Lane (2000). In order to address the intratemporal aspects of the problem, three main assumptions are made. First, importable is consumed but not produced, and exportable is produced but not consumed. In other words, the import and the nontradables are consumed domestically but the export and the nontradable are produced domestically. Second, investment is held constant where the capital stock is an endowment which is not affected by the terms-of-trade shocks. Third, the economy is small in the sense that it can influence neither the world interest rate nor the terms-of-trade of the economy ${ }^{5}$. We also assume that the output of the traded goods sector is an endowment of $y_{T}$ which is sold in the world markets at the export price of $P_{T}^{x}$, where $P_{T}^{x}$ is measured in units of the imported consumption good, which is used as the numeraire. Since consumption of the export goods is assumed to be zero, $P_{T}^{x}$, by definition is the terms-of-trade and is exogenous to the

\footnotetext{
${ }^{5}$ Many (Senhadji, 1998 and Backus et al., 1994) have modeled terms-of-trade as an endogenous variables. However, by studying Granger-Simes statistical causality, Mendoza found that except for the United States and a few major fuel exporters, the null hypothesis of exogeneity of terms-of-trade for small open economies cannot be rejected.
} 
country.

Consider an economy populated by a continuum of yeoman-farmers along the unit interval $[0,1]$. The representative agent aims to maximize the intertemporal utility function which is given by

$$
V_{j}=\sum_{t=0}^{\infty} \beta^{t}\left[\frac{\sigma}{\sigma-1} C_{t}^{\frac{\sigma-1}{\sigma}}-\frac{k}{2} y_{N t}^{2}(j)\right]
$$

where $\beta \in(0,1), \sigma, k>0 . \quad \beta$ is a preference parameter which called the subjective discount or time preference factor and $\sigma$ is the intertemporal elasticity of substitution. The consumption index $\mathrm{C}$ aggregates the consumption of traded and nontraded goods,

$$
C_{t}=\left[\gamma^{\frac{1}{\theta}} C_{T t}^{\frac{\theta-1}{\theta}}+(1-\gamma)^{\frac{1}{\theta}} C_{N t}^{\frac{\theta-1}{\theta}}\right]^{\frac{\theta}{\theta-1}}
$$

where $\theta>1$ which is the intratemporal elasticity of substitution between the traded and nontraded goods. $y_{N I}(j)$ is the production of $j$-th variety of the nontraded goods. The second terms in the objective function in (1) captures the disutility of work effort.

The dynamic budget constraint is

$$
B_{t+1}=(1+r) B_{t}+p_{N t}(j) y_{N t}(j)+P_{T}^{x} y_{T}-P_{t} C_{t}
$$

where agent invests in an international real bond, $B_{t}$, denominated in units of the import good that pay off a real return $r$, which is exogenously determined. Each agent also receives an exogenous endowment of traded good $y_{T t}$ each period. The consumption price index is given by

$$
P_{t}=\left[\gamma+(1-\gamma) P_{N t}^{1-\theta}\right]^{\frac{\theta}{1-\theta}}
$$

Agent $j$ is the monopoly producer of variety $j$ of the nontraded goods and faces the demand function

$$
y_{N t}^{d}(j)=\left[\frac{p_{N t}(j)}{p_{N t}}\right]^{-\mu} C_{N t}^{A} \quad \mu>1
$$

where $C_{N}^{A}$ is the aggregate consumption of nontraded goods and the index functions for nontraded consumption and price can be written as 


$$
\begin{aligned}
& C_{N t}=\left[\int_{0}^{1} c_{N}(z)^{\frac{\mu-1}{\mu}} d z\right]^{\frac{\mu}{\mu-1}} \\
& P_{N t}=\left[\int_{0}^{1} p_{N}(z)^{1-\mu} d z\right]^{\frac{1}{1-\mu}}
\end{aligned}
$$

\section{A. First Order Conditions}

Assuming that there is no desire to borrow and lend at the steady state, therefore $\beta(1+r)=1$. Maximize the objective function with respect to $B_{t+1}, C_{N t}, y_{N t}$ subject to the dynamics budget constraint and assuming no-Ponzi-Game condition yields the following first order conditions:

$$
\begin{gathered}
\frac{C_{t+1}}{C_{t}}=\left[\frac{P_{t}}{P_{t+1}}\right] \Leftrightarrow \frac{C_{T t+1}}{C_{T t}}=\left[\frac{P_{t}}{P_{t+1}}\right]^{\sigma-\theta} \\
\frac{C_{N t}}{C_{T t}}=\frac{1-\gamma}{\gamma}\left(P_{N t}\right)^{-\theta} \\
y_{N t}^{\frac{\mu+1}{\mu}}=\frac{\mu-1}{\mu k}\left[\frac{P_{N t}}{P_{t}}\right]\left(C_{N t}^{A}\right)^{\frac{1}{\mu}} C_{t}^{-\frac{1}{\sigma}}
\end{gathered}
$$

Equation (8) is the intertemporal Euler equation. This equation which governs the dynamics of consumption can be rewritten as the consumption-based real interest rate ${ }^{6}$. If the aggregate price level relative to the price of traded goods is currently higher than its future value, there will be a change in the consumption of traded and nontraded goods due to the inter- and intratemporal substitution effects. First, since the current aggregate price level relative to traded goods is higher (the consumption-based real interest rate is higher), agents may choose to postpone or delay their consumption. This increase raises the optimal growth rate of real consumption with the intertemporal elastiticity of substitution, $\sigma$ where $C_{t}<C_{t+1}$ or $C_{T t}<C_{T t+1}$. Second, it also encourages substitution from nontraded to traded goods as traded goods become relatively cheaper and rises as a fraction of consumption with intratemporal elasticity of substitution, $\theta$. These intertermporal and intra-

${ }^{6}$ Refer to Obstfeld and Rogoff (1996, Chapter 4). When the current price is higher relative to the future price, the consumption-based real interest rate is also higher as $\left(1+r_{t+1}^{c}\right)=(1+r) P_{t} / P_{t+1}$. 
temporal substitution on consumption of traded goods work exactly in opposite directions. It is also interesting to take notes that if price is constant or $s=\mathrm{q}$, current consumption equals to future consumption. In other words, the gross growth rate of real consumption path is flat.

Equation (9) shows the relationship between the consumption of traded and nontraded goods. The elasticity between the two goods is parameterized by $\theta$. Finally, equation (10) shows that the production of nontraded goods is inversely related to the consumption index, $\mathrm{C}$.

\section{B. Steady State Equilibrium}

All variables are assumed to be constant at the steady state. Assuming that the level of initial net foreign assets is zero i.e. $\overline{B_{0}}=0^{7}$. We normalize the endowment of the traded goods so that the relative price of nontraded goods in terms of traded goods $P_{N}$ is unity in the steady state, $\bar{P}_{N 0}=1$ and we also assume that the terms-of-trade, $\bar{P}_{T 0}^{x}=1$ at the initial steady state. In this symmetric equilibrium, $\bar{C}_{N}^{A}=\bar{C}_{N}=\bar{y}_{N}=(1-\gamma) \bar{C}$ and the steady state consumption and production of traded and nontraded goods are

$$
\begin{gathered}
\bar{y}_{t}=\bar{C}_{T}=\frac{\gamma}{1-\gamma} \bar{C}_{N} \\
\bar{y}_{N}=\bar{C}_{N}=\left[\frac{\mu-1}{\mu k}\right]^{\frac{\sigma}{\sigma+1}}(1-\gamma)^{\frac{1}{\sigma+1}}
\end{gathered}
$$

Equation (12) shows that the production and consumption of nontraded goods are directly related to the level of competition in the nontraded goods sector i.e. the larger is $\mu$, the larger is the steady state production and consumption of nontraded goods. From this expression, it is also true that the production and consumption of nontraded goods will be larger, the less taxing is work effort (the smaller is $k$ ) and the larger is the weight placed on the consumption of nontraded goods in the utility function (the larger is $1-\gamma$ ).

\section{The Log-linearized Version of FOC and Other Conditions}

In this section, we develop the linearized version of all the model's equilibrium

\footnotetext{
${ }^{7}$ The 0 subscripts on barred variables denote the initial preshock symmetric steady state. For instance, $\bar{X}_{0}$ is the initial steady state value of variable $X$.
} 
conditions. We begin with the three first order conditions:

$$
\begin{gathered}
\tilde{C}_{T t+1}-\tilde{C}_{T t}=(\sigma-\theta)\left(\tilde{P}_{t}-\tilde{P}_{t+1}\right) \\
\tilde{C}_{N t}-\tilde{C}_{T t}=-\theta \tilde{P}_{N t} \\
\tilde{y}_{N t}=-\frac{1}{\sigma} \tilde{C}_{t}+\left(\tilde{P}_{N t}-\tilde{P}_{t}\right)
\end{gathered}
$$

and log-linearized versions of the consumption price index and consumption index are

$$
\begin{gathered}
\tilde{P}_{t}=(1-\gamma) \tilde{P}_{N t} \\
\tilde{C}_{t}=\gamma \tilde{C}_{T t}+(1-\gamma) \tilde{C}_{N t}
\end{gathered}
$$

The impact of steady state variation in net foreign asset $(B)$, tradable output $\left(y_{T}\right)$ and the terms of trade $\left(P_{T}^{x}\right)$ can be derived by taking the linear approximation of (2) around the steady state which yields

$$
\frac{d B_{t+1}}{\bar{C}_{T 0}}=(1+r) \frac{d B_{t}}{\bar{C}_{T 0}}+\tilde{y}_{T t}+\tilde{P}_{T t}^{x}+\tilde{C}_{T t}
$$

Change in the net foreign assets in period $t+1$ equals to the sum of net foreign assets together with its interest return in period $t$, change in the endowment of traded output, and change in the terms-of-trade minus the change in the consumption of traded goods.

\section{An Unanticipated Permanent Terms-of-Trade Shock}

We now investigate the effects of an unanticipated permanent terms-of-trade shock that occurs at time 1 . Prices in the competitive traded goods sector are fully flexible prices while prices in the nontraded goods sector are set one period in advance and adjust to flexible price levels only after a period in the absence of new shocks. In the event of an unanticipated permanent terms-of-trade shock, rational agent can only adjust its price one period later. With sticky nominal prices, the economy reaches the steady state equilibrium only in the long run i.e. given the structure of the nominal rigidity, the new steady state is attained after one period. 
To distinguish between the short run and the long run effects of the terms-of-trade shock we let $\tilde{X} \equiv\left(X_{1}-\bar{X}_{0}\right) / \bar{X}_{0}$ to denote the short run percentage deviation in $X$ from $\bar{X}_{0}$, the initial steady state value of $X$, and $\hat{X} \equiv\left(\bar{X}-\bar{X}_{0}\right) / \bar{X}_{0}$ to denote the long run steady state percentage deviation.

We first consider an unanticipated permanent favorable terms-of-trade shock, $\hat{P}_{T}^{x}=\tilde{P}_{T}^{x}>0$. Since the nontraded goods sector is assumed to be a monopolistic market and prices in this sector are set one period in advance, they adjust to the shock only by period two. In the short run, prices in the nontraded goods sector are fixed and nontraded output is demand determined. Therefore, we have

$$
\begin{gathered}
\tilde{P}_{N}=0 \\
\tilde{C}_{N}=\tilde{y}_{N}
\end{gathered}
$$

which implies from (14) the relationship between $\tilde{C}_{N}$ and $\tilde{C}_{T}$

$$
\tilde{C}_{N}=\tilde{C}_{T}
$$

With $P_{N}$ fixed, the short run and the long run change in the consumption-based price index are

$$
\begin{gathered}
\tilde{P}=0 \\
\hat{P}=(1-\gamma) \hat{P}_{N}
\end{gathered}
$$

the relationship between $\hat{C}_{T}$ and $\tilde{C}_{T}$ are linked by

$$
\hat{C}_{T}-\tilde{C}_{T}=-(\sigma-\theta)(1-\gamma) \hat{P}_{N}
$$

From (18), given a constant endowment of the traded goods, the steady state consumption of traded goods can only be increased by the income earned from the accumulation of net foreign assets and the change in the terms-of-trade

$$
\hat{C}_{T}=r \hat{b}+\hat{P}_{T}^{x}
$$

where $\hat{b}=\frac{d B}{\bar{C}_{T 0}}$. In turn the accumulation of foreign assets $d B$ is generated by 
the short run current account surplus

$$
\hat{b}=\hat{P}_{T}^{x}-\tilde{C}_{T}
$$

The supply condition (15) and the optimize relationship between $\tilde{C}$ and $\tilde{C}_{N}$ give

$$
\tilde{Y}_{N}=\tilde{C}_{N}=\frac{\sigma-\theta}{1+\sigma}\left(\hat{P}_{N}-\hat{P}\right)
$$

Lastly, from the consumption optimization condition between the traded and the nontraded goods (14)

$$
\tilde{C}_{N}-\tilde{C}_{T}=-\theta \hat{P}_{N}
$$

Equations (19)-(28) allow us to solve for both the short run and the steady state effects of an unanticipated favorable terms-of-trade shock.

The solution has the following form

$$
\begin{gathered}
\hat{y}_{N}=\hat{C}_{N}=\frac{(\sigma-\theta)(1+r)}{a_{0}} \hat{P}_{T}^{x} \\
\hat{C}_{N}=\frac{(1+r)[\theta(1-\gamma)+\sigma(\theta+\gamma)]}{a_{0}} \hat{P}_{T}^{x} \\
\hat{P}_{N}=\frac{(1+r)(1+\sigma)}{a_{0}} \hat{P}_{T}^{x} \\
\hat{P}=\frac{(1+r)(1+\sigma)(1-\gamma)}{a_{0}} \hat{P}_{T}^{x} \\
\hat{C}=\frac{\gamma \sigma(1+r)(1+\theta)}{a_{0}} \hat{P}_{T}^{x} \\
\hat{b}=\frac{(1-\gamma)(\sigma-\theta)(1+\sigma)}{a_{0}} \hat{P}_{T}^{x} \\
\tilde{C}_{T}=\tilde{C}_{N}=\tilde{y}_{N}=\frac{\sigma(1+r)[\sigma(1-\gamma)+(1+\theta \gamma)]}{a_{0}} \hat{P}_{T}^{x} \\
\hat{C}_{T}-\tilde{C}_{T}=\frac{(\sigma-\theta)(1+r)(1-\gamma)(1+\sigma)}{a_{0}} \hat{P}_{T}^{x}
\end{gathered}
$$

where $a_{0}=r \sigma^{2}(1-\gamma)+\theta(1-\gamma)+r \sigma(1+\theta \gamma)+\sigma(\theta+\gamma)>0$.

There are three cases to consider: (i) $\sigma=\theta$, (ii) $\sigma>\theta$ and (iii) $\sigma<\theta$. With an 
unanticipated permanent improvement in the terms-of-trade, the economy is perturbed in both the short run and the long run. The results show that the effects of an unanticipated permanent improvement in the terms-of-trade on the current account will depend upon the inter- and intra- elasticities of substitution ${ }^{8}$. All the three cases can be clearly summarized in the following table:

Table 1. Effects of an unanticipated permanent terms-of-trade shock

\begin{tabular}{cccc}
\hline & $\sigma=\theta$ & $\sigma>\theta$ & $\sigma<\theta$ \\
\hline$\hat{y}_{N}=\hat{C}_{N}$ & 0 & + & + \\
$\hat{C}_{T}$ & + & + & + \\
$\hat{C}$ & + & + & + \\
$\hat{P}_{N}$ & + & + & + \\
$\hat{P}$ & + & + & + \\
$\hat{b}$ & 0 & - & + \\
$\hat{C}_{T}-\tilde{C}_{T}$ & 0 & - & + \\
$\tilde{C}_{N}=\tilde{C}_{T}=\tilde{y}_{N}$ & + & + & + \\
\hline
\end{tabular}

In case (i) when $\sigma=\theta$, a permanent terms-of-trade improvement will only lead to an increase in the consumption of traded goods in both the short run and the long run by equal proportion without any real effect on the holding of net foreign asset. Current account is balanced as in the initial steady state. Since the elasticities of intertemporal and intratemporal substitution are equal, there is no spillover effect from the traded goods sector to the nontraded goods sector in the long run. Hence the output and the consumption of nontraded goods in period two remain unchanged.

However, in case (ii) when $\sigma>\theta$, the elasticity of intratemporal substitution is low (relative to the elasticity of intertemporal substitution) which implies that traded goods and nontraded goods are poor substitutes or good complements. A permanent terms-of-trade improvement induces a rise in the consumption of traded goods $\hat{C}_{T}>0$, which further stimulates extra demand in the nontraded goods sector, $\hat{C}_{N}>0$. Since price of nontraded goods is sticky in the short run, $\tilde{P}_{N}=0$ but increase in the long run, $\hat{P}_{N}>0$, traded goods (importables) are relatively cheaper than nontraded goods in the short run. Since the price of nontraded goods

${ }^{8}$ In the Appendix, we show that without nominal rigidities and imperfect competition, a permanent termsof-trade deterioration does not have any effect on the current account of a small open economy. As a result, fluctuation in the current account due to a permanent terms-of-trade shock is purely a result of nominal rigidities and imperfect competition in this setup. 
is rising in the long run, the price gap between tradables and nontradables are even larger in the long run. As a result, when traded and nontraded goods are good complements, we expect the increase in the consumption of traded goods in the short run is larger the increase in the long run, $\hat{C}_{T}<\tilde{C}_{T}$. When the permanent terms-of-trade shock causes a large increase in the consumption of traded goods in the short run, there is a decumulation in the holding of net foreign assets, $\hat{b}<0$. It is because of this asymmetric adjustment in the consumption of traded goods in the short run and the long run that brings to a decrease in the holding of net foreign assets, in order words, the current account goes into deficit and $\hat{C}_{T}<\hat{P}_{T t}^{x}<\tilde{C}_{T}$.

On the other hand, in case (iii) when $\sigma<\theta$, the elasticity of intratemporal substitution is relatively large compared to the elasticity of intertemporal substitution, traded goods and nontraded goods are close substitutes. A permanent terms-of-trade improvement raises the consumption of traded goods, $\hat{C}_{T}>0$ which further contracts the demand for nontraded goods, $\hat{C}_{T}<0$. Since prices of nontraded goods are sticky in the short run but increases after one period, the long run increase in the consumption of traded goods is larger than the short run, $\hat{C}_{T}>\tilde{C}_{T}$. Since the increase in the consumption of traded goods in the short run is relatively small, this will enhance an accumulation in the holding of net foreign assets which enables for a larger increase in the consumption of traded goods in the long run. As a result of this asymmetric adjustment, the current account goes into surplus and $\hat{C}_{T}>\hat{P}_{T t}^{x}>\tilde{C}_{T}$.

From this simple but rigorous analysis, the effect of favorable permanent termsof-trade shocks on the current account depends critically on the adjustments of consumption in traded goods in both the short run and the long run. These adjustments, in turn, depend significantly on the relationship between the traded and nontraded goods. If the two goods are substitutes, in the presence of nominal price rigidities in the nontraded goods sector, a permanent improvement in termsof-trade generates an increase in the holding of net foreign assets and hence current account surplus. On the other hand, if the two goods are good complements, a permanent improvement in terms-of-trade leads to a current account deficit.

\section{An Unanticipated Temporary Terms-of-Trade Shock}

With an unanticipated temporary terms of trade shock, $\hat{P}_{T}^{x}<0$ and $\hat{P}_{T}^{x}=0$. All equations from (19)-(28) remain unchanged except equations (25) and (26) which will change to 


$$
\begin{gathered}
\hat{C}_{T}=r \hat{b} \\
\hat{b}=\tilde{P}_{T}^{x}-\tilde{C}_{T}
\end{gathered}
$$

Solve (19)-(24), (25a), (26a) and (27)-(28) simultaneously to analyze the short run and the long run effects of an unanticipated temporary improvement in termsof-trade disturbance yields the following form of solution:

$$
\begin{gathered}
\hat{y}_{N}=\hat{C}_{N}=\frac{r \gamma(\sigma-\theta)}{a_{0}} \tilde{P}_{T}^{x} \\
\hat{C}_{T}=\frac{r[\theta(1-\gamma)+\sigma(\theta+\gamma)]}{a_{0}} \tilde{P}_{T}^{x} \\
\hat{P}_{N}=\frac{r(1+\sigma)}{a_{0}} \tilde{P}_{T}^{x} \\
\hat{P}=\frac{r(1+\sigma)(1-\gamma)}{a_{0}} \tilde{P}_{T}^{x} \\
\hat{C}=\frac{\gamma \sigma r(1+\theta)}{a_{0}} \tilde{P}_{T}^{x} \\
\hat{b}=\frac{\theta(1-\gamma)+\sigma(\theta+\gamma)}{a_{0}} \tilde{P}_{T}^{x} \\
\tilde{C}_{T}=\tilde{C}_{N}=\tilde{y}_{N}=\frac{\sigma r[\sigma(1-\gamma)+(1+\theta \gamma)]}{a_{0}} \tilde{P}_{T}^{x} \\
\hat{C}_{T}-\tilde{C}_{T}=-\frac{r(\sigma-\theta)(1-\gamma)(1+\sigma)}{a_{0}} \tilde{P}_{T}^{x}
\end{gathered}
$$

The effects of a temporary favorable shock on a small open economy are summarized as follows:

Table 2. Effects of an unanticipated temporary terms-of-trade shock

\begin{tabular}{cccc}
\hline & $\sigma=\theta$ & $\sigma=\theta$ & \\
\hline$\hat{y}_{N}=\hat{C}_{N}$ & 0 & + & - \\
$\hat{C}_{T}$ & + & + & + \\
$\hat{C}$ & + & + & + \\
$\hat{P}_{N}$ & + & + & + \\
$\hat{P}$ & + & + & + \\
$\hat{b}$ & + & + & + \\
$\hat{C}_{T}-\tilde{C}_{T}$ & 0 & - & + \\
$\tilde{C}_{N}=\tilde{C}_{T}=\tilde{y}_{N}$ & + & + & + \\
\hline
\end{tabular}


Notice that even though the shock is temporary, the traded goods are relatively cheaper than the nontraded goods in both the short run and the long run. This is mainly due to the increase in the prices of the nontraded goods in the long run even after a temporary terms-of-trade shock. In this case, the model generates an increase in the consumption of traded goods in both periods and a rise in the holding of net foreign assets, $\hat{b}>0$ in response to a positive temporary terms-oftrade shock regardless of the size of the elasticities of intertemporal, $\sigma$ and intratemporal, $\theta$ substitution. When the terms of trade improves, it induces the consumption of traded goods to increase but by less than the proportionate change in terms-of-trade, i.e. $\tilde{C}_{T}<\tilde{P}_{T}^{x}$. This is perhaps due to the consumption-smoothing behaviour of the rational agents. As a result, a positive temporary terms-of-trade shock always brings the current account into surplus and this accumulation of net foreign assets allows for a higher consumption of traded goods in the long run, $\tilde{C}_{T}>0$. However, the effects of positive terms-of-trade shocks on the output and consumption of nontraded goods depend critically on the relative size of the two elasticities. There are three cases to consider: (i) $\sigma=\theta$, (ii) $\sigma>\theta$ and (iii) $\sigma<\theta$.

In case (i), the utility function is in the form of log-separable. A temporary terms-of-trade improvement immediately induces the consumption of traded goods in the short run. Traded goods are relatively cheaper in both the short run and the long run. Hence, there is also an increase in the consumption of traded goods in the long run. However, the intertemporal and intratemporal substitution effects cancel out, so that there is no spillover on the consumption of nontraded goods in the long run. Effects of a favorable temporary terms-of-trade shock are the same for the consumption of traded goods in both the short run and the long run.

In case (ii), a rise in the consumption of traded goods in the long run, $\tilde{C}_{T}>0$ stimulates an expansion in the production and consumption in the nontraded goods sector, $\tilde{C}_{N}>0$. This is mainly a result of relatively low elasticity of substitution between traded goods and nontraded goods (relative to the intertemporal elasticity of substitution). It is also interesting to note that in this case, due to the rise in the prices of nontraded goods in the long run and low elasticity of intratemporal substitution, the impacts of a temporary improvement in the terms-of-trade on the consumption of traded goods is larger in the short run, $\hat{C}_{T}<\tilde{C}_{T}$.

In case (iii), as a result of relatively larger elasticity of intratemporal substitution, the spillover between traded and nontraded consumption is negative. A surge in the consumption of traded goods, $\tilde{C}_{T}>0$ contracts the production and consumption in the nontraded goods sector, $\hat{C}_{N}<0$. Moreover, the traded and nontraded goods are 
substitutes in this case, the adverse impacts on the consumption of traded goods is smaller in the short run, $\hat{C}_{T}>\tilde{C}_{T}$.

\section{Conclusion}

This model which captures the spirit of the recent intertemporal sticky price literature has clearly demonstrated the effects of an adverse terms-of-trade on current account - both temporary and permanent. The model predicts a few outcomes. First, the current account always goes into surplus (deficit) with a temporary terms-of-trade improvement (deterioration) and the result holds with or without nominal rigidities. Second, in the presence of nominal rigidities and imperfect competition, a permanent terms-of-trade improvement may cause the current account to move in either direction, surplus or deficit, depends critically on the relative elasticities of intertemporal and intratemporal substitution. Third, the impacts of a terms-of-trade on consumption and output of nontraded goods in the long run $\left(\hat{C}_{N}\right.$ and $\left.\hat{y}_{N}\right)$, price of nontraded goods in the long run $\left(\hat{P}_{N}\right)$, overall price in the long run $(\hat{P})$, consumption of traded goods $\left(\tilde{C}_{T}\right)$ and consumption and output of nontraded goods in the short run $\left(\tilde{C}_{N}\right.$ and $\left.\tilde{y}_{N}\right)$ are magnified when the shock is permanent. Finally, when prices are perfectly flexible, the intertemporal Euler equation shows that the optimal consumption growth path is flat. As a result, the holding of net foreign assets remains unchanged even when the terms-of-trade shock is permanent.

This study shows results that are consistent with others (Sach, 1981; Obstfeld, 1982; Svensson and Razin, 1983) who argue that HLM effect only holds true for temporary terms of trade shocks. In this model, a temporary positive terms-of-trade shock induces a relatively higher prices in the nontraded goods sector in both the short run and the long run. In the short run, with sticky prices in the nontraded goods, a positive terms-of-trade shock will result in relatively higher prices of nontraded goods as price of traded goods is lower but the price of nontraded goods remains unchanged. In the long run, a temporary terms-of-trade shock will cause a rise in the prices of nontraded goods but the price of traded goods returns back to its initial level. Hence, after the temporary terms-of-trade shock ceases, the prices in the nontraded goods sector remain relatively higher. As a result, stickiness in the nontraded goods sector will generate an increase in the consumption of traded goods in both periods. However, since the consumption of traded goods rises by less than the terms-of-trade, the holding of net foreign assets is always higher. 
In contrast to the Obstfeld-Svensson-Razin model which finds that permanent terms-of-trade shocks leave the current account unchanged, this model shows that permanent terms-of-trade may have a positive effect or negative effect on the current account in the presence of nominal rigidities and imperfect competition. The impact of a permanent terms-of-trade shock on the current account depends critically on the degree of substitutability between the traded and nontraded goods. When prices are perfectly flexible, permanent terms-of-trade shocks do not affect the holding of net foreign assets.

In conclusion, permanent changes in terms-of-trade do not affect the current account when prices are perfectly flexible, whereas temporary changes do, temporary improvement causing surpluses and temporary decline producing deficit.

Received 25 March 2004, Accepted 17 December 2004

\section{References}

Backus, D. K. (1993) Interpreting comovements in the trade balance and the terms of trade. Journal of International Economics, 34, 375-387.

Backus, D. K., Kehoe, P. J., Kydland, F. K. (1994) Dynamics of the trade balance and the terms of trade: The J-curve. American Economic Review, 84(1), 89-103.

Cardia, E. (1991) The dynamics of a small open economy in response to monetary, fiscal and productivity shocks. Journal of Monetary Economics, 28, 411-434.

Cashin, P. and McDermott C. J. (1998) Terms of trade shocks and the current account, International Monetary Fund Working Paper WP 98/177.

Edwards, S. (1989) Temporary terms of trade disturbances, the real exchange rate and the current account, Economica, 56, 343-357.

Gavin, M. (1990) Structural adjustment to a terms of trade disturbance: The role of relative prices, Journal of International Economics, 28, 217-243.

Harberger, A. C. (1950) Currency Depreciation, Income and the Balance of Trade, Journal of Political Economy, 58, 47-60.

Kose, M. A. (2002) Explaining business cycles in small open economies: 'How much do world prices matter', Journal of International Economics, 56, 299 - 327.

Lane, P. R. (2000) The transfer problem revisited: Net foreign assets and real exchange rates, International Monetary Fund Working Paper WP 00/123.

Lane, P. R. (2001) Money and the current account, money, factor mobility and trade: Essay in honor of Robert Mundell, Cambridge, MA: MIT Press.

Lane, P.R. (2001) The new open economy macroeconomics: A survey, Journal of International Economics, 54, 235-266. 
Laursen, S. and Metzler L.A. (1950) Flexible exchange rates and the theory of employment, Review of Economics and Statistics, 32, 281-299.

Mendoza, E. G. (1995) The terms of trade, the real exchange rate and economic fluctuations. International Economic Review, 36(1), 101-137.

Obstfeld, M. (1983) Aggregate spending and the terms of trade: Is there a LaursenMetzler Effect? Quarterly Journal of Economics, 97, 251-270.

Obstfeld, M. (2002) Exchange rates and adjustment: perspectives from the New Open Economy Macroeconomics. Bank of Japan's $10^{\text {th }}$ International Research Conference.

Obstfeld, M. and Rogoff K. (1996) Foundations of international macroeconomics, Cambridge, MA: MIT Press.

Persson, T. and Svensson L.E.O. (1985) Current account dynamics and the terms of trade: Harberger-Laursen-Metzler two generations later, Journal of Political Economy, 93, 43-65.

Sachs, J. (1981) The current account and macroeconomic adjustment process, National Bureau of Economic Research Working Paper 796.

Senhadji, A. S. (1998) Dynamics of the trade balance and the terms of trade in LDCs: The S-curve, Journal of International Economics, 46, 105-131.

Svensson, L.E.O. and A. Razin (1983) The terms of trade and the current account: The Harberger-Laursen-Metzler effect, Journal of Political Economy, 91, 97-125. 


\section{Appendix}

\section{(i) Permanent terms-of-trade shock with perfect price flexibility and perfectly competitive markets}

In the absence of nominal rigidities and assume that the markets are perfectly competitive, the model shows that an unanticipated permanent terms-of-trade shock does not have any effect on the current account. This prediction is consistent with the Obstfeld-Svensson-Razin model. When prices are perfectly flexible, Equation (13) $\tilde{C}_{T t+1}-\tilde{C}_{T t}=(\sigma-\theta)\left(\tilde{P}_{t}-\tilde{P}_{t+1}\right)$ shows that $\tilde{C}_{T t+1}=\tilde{C}_{T t}$, since $\tilde{P}_{N t} \neq 0$ and $\tilde{P}_{t}=\tilde{P}_{t+1}=(1-\gamma) \tilde{P}_{N t} \neq 0$. By solving this model accordingly, we obtain the following results:

$$
\begin{gathered}
\tilde{C}_{N}=\tilde{C}_{N}=\tilde{y}_{N}=\hat{y}_{N}=\frac{\gamma(\sigma-\theta)}{b_{0}} \hat{P}_{T}^{x} \\
\tilde{C}_{T}=\hat{C}_{T}=\hat{P}_{T}^{x}
\end{gathered}
$$

and the accumulation of net foreign assets is

$$
\hat{b}=0
$$

where $b_{0}=\theta(1-\gamma)+\sigma(\theta+\gamma)>0$. It is also noted that when $\sigma>\theta$, the elasticity of intratemporal substitution is low relative to the elasticity of intertemporal substitution which implies that traded and nontraded goods are poor substitutes, a permanent terms-of-trade deterioration has a contractionary effect on the nontraded goods sector and vice versa.

\section{(ii) Temporary terms-of-trade shock with perfect price flexibility and perfectly competitive markets}

In this setup, when prices are perfectly flexible and nontraded goods sector is perfectly competitive, a temporary terms-of-trade shock will always deteriorate the current account. Our model shows that

$$
\tilde{C}_{T}=\hat{C}_{T}=\frac{r}{1+r} \tilde{P}_{T}^{x}
$$

and the accumulation of net foreign assets is

$$
\hat{b}=\frac{1}{1+r} \tilde{P}_{T}^{x}
$$


When there is a temporary adverse terms-of-trade shock, the consumption smoothing behaviour of the individuals induces them to decrease the consumption of traded goods in the short run by less than the amount of the shock. As a result, there is a decumulation of net foreign assets. It should also be noted that in the absence of nominal rigidities, the change in the consumption of traded goods in the short run equals to the change in the consumption of traded goods in the long run. 